\title{
THE SETTLEMENT OF DISPUTES AMONG MEMBERS OF THE ORGANISATION OF AFRICAN UNITY
}

\author{
By Zdenek Červenka
}

In the peaceful settlement of disputes the record of the OAU is certainly more impressive than that of the United Nations Organisation. Direct negotiations between States, good offices or mediation offered by a third party or by ad hoc committees composed of the Heads of State, diplomacy conducted during sessions of the Assembly of Heads of State and Governments, produced excellent results. An unusual feature of the OAU's handling of disputes is that not one single dispute was ever dealt with by the organ created specifically for that purpose: The Commission of Mediation, Conciliation and Arbitration. Established in 1964, it was regarded by the Chairman of the drafting committee and chief architect of the Commission Dr. T. O. Elias of Nigeria "raison d'etre of the Organisation".

The Commission was designed to be one of the four principal institutions of the OAU. It was set up as an autonomous body with its own Protocol which forms an integral part of the Charter of the OAU2.

The Commission was getting off the ground very slowly. The OAU Assembly meeting in Accra in October 1965, appointed 21 Members of the Commission headed by its President Justice M. A. Odesanya of Nigeria and two Vice-Presidents (Dr. August R. N. Gandzadi of the Congo and Dr. William C. Daniels of Ghana) ${ }^{3}$. The only attempt to make a use of the Commission was made in 1967 concerned the case of the detention of Guinea officials in retaliation for "arbitrary arrest" by Guinea of several citizens of Ivory Coast and the capture of a fishing trawler suspected that its crew had plotted to kidnap former President of Ghana Kwame Nkrumah living in Guinea. But little could be done by the Commission

1 This is how Dr. T. O. Elias, who was Chairman of the Drafting Committee which met in Cairo in April 1964 to work on the Protocol, the Commission of Mediation, Conciliation and Arbitration describes the importance of the Commission:

"The importance of the Commission of Mediation, Conciliation and Arbitration described in the present Protocol cannot be over-emphasized. Within the framework of the OAU nothing is more central to the problem of unity and solidarity than the maintenance of good relations and neighbourliness among the Member States. Indeed, it can be said that this Commission in large part supplies the raison d'être of the Organization. All the Specialized Commission will no doubt play their several significant parts in the promotion of the economic, social and cultural well-being of the communities of the Member States, and it is on the extent to which they fulfil these aspirations of the peoples of Africa that the success of the Organization will be judged. But the peaceful resolution of conflicts, both large and small within the framework of the Organization, provides the necessary condition for orderly progress, not only for the individual Member States, but also for the entire continent of Africa. It is to be hoped that more and more use of the Commission of MCA will be made by Member States as a forum for the amicable settlement of their disputes, thereby reducing the occasions.for international

conflicts and misunderstandings."
T. O. Elias: "The Commission of Mediation, Conciliation and Arbitration of the Organisation of African Unity". In: British Year Book of International Law. London, Vol. 41, 1964, p. 348.

2 Article 19 provides: "Member States pledge to settle all disputes among themselves by peaceful means and to this end decide to establish a Commission of Mediation, Conciliation and Arbitration, the composition of which and conditions of services shall be defined in a separate Protocol to be approved by the Assembly of Heads of State and Government. The said Protocol shall be regarded as forming an integral part of the present Charter."

3 The following were the other members of the Commission appointed by the Assembly: Mr. Libere NDABKWATE, Burundi; Mr. P. L. Benjamin BEB a DON, Cameroon; Mr. Getachew KEBRETH, Ethiopia; Mr. Sikhe CAMERA, Guinea; Mr. J. L. KAMERE, Kenya; Mr. Joseph W. GARBER, Liberia; Mr. Ahmed BEN LAMIN, Libya; Mr. Demba DIALLO, Mali; Mr. Zentar MEHDI MRANI, Morocco; Dr. Mohamed Hafez GHANEM, Egyp; Mr. Jeseph NDIBWAMI, Rwanda; Mr. Ousman Goundiam, Senegal; Mr. Berthan MACAULEY, Sierra Leone; Mr. Mohamed SCHEIK AHMED, Somalia; Mr. Ahmed MUTWALLI EL ATABINI, Sudan; Mr. Earle Edward SEATON, Tanzania; Mr. H. L. BINAISA, Uganda; Mr. M. CHONA, Zambia. 
because one of its Vice-Presidents, Dr. E. Daniels of Ghana was detained by the military-police clique which deposed Dr. Nkrumah. When the Commission finally met, three and half years after its establishment, in December 1967 in Addis Ababa it had already become clear that the OAU had embarked on a totally different course for the settlement of disputes than that envisaged by the Charter and the Protocol of the Commission. The African leaders, however, still believed in its usefulness. Emperor Haile Selassie addressed the opening session of the Commission in 1967 in the following words:

"This Commission occupies a special place in the Charter of the OAU as one of its four principal institutions. There is nothing that is closer to our hearts than the work with which it is entrusted in the peaceful settlement of disputes; it is a task of great significance, for without conditions of security and peace none of the objectives and aspirations enshrined in the Charter can be realized.4"

Before discussing the reasons for excluding the Commission by the Member States in the search for the peaceful settlement of their disputes it is necessary to describe briefly the modes of settlement offered by the Commission.

The terms of reference of the Commission on Mediation, Conciliation and Arbitration are set forth in the Protocol. It provides for the following three means of settlement of disputes:

\section{Mediation ${ }^{5}$ \\ 2. Conciliation 6 \\ 3. Arbitration?}

4 Quoted in the Report on the Commission of Mediation, Conciliation and Arbitration by its President, Justice M. A. Odesanya of Nigeria submitted to the Fifteenth Ordinary Session of the Council of Ministers in Addis Ababa in August 1970 which is a brilliant analysis of the Commission's history, reasons for its inactivity and a survey of proposals for its reactivation. CM/334/Add. 1 .

5 MEDIATION. According to Article XXI, "the role of the mediator shall be confined to reconciling the views and claims of the parties. The mediator shall make written proposals to the parties as expeditiously as possible. If the means of reconciliation proposed by the mediator are accepted, they shall become the basis of a protocol of arrangement between the parties". No rules of procedure are followed in mediation, proceedings are confidential and the mediator can only give advice and recommendations to the parties. Similarly, the method of good offices consists of a third State, an international organisation or an individual, attempting to bring the disputing parties together for negotiations, especially when diplomatic relations have been broken off. Contrary to mediation, good offices do not involve any active assistance in reaching a settlement, apart from reestablishing contact between the disputants.

6 CONCILIATION. According to Article XXIV of the Protocol, the duty of conciliators established in pursuance of Articles XXII and XXIII, which describe the procedure of conciliation, is to "clarify the issues in dispute and to endeavour to bring about an agreement between the parties upon mutually acceptable terms". The Conciliation Commission is therefore expected to propose terms of settlement to the parties. However, its proposals are not binding upon the parties, being purely recommendatory. The Commission is in no way limited to basing its recommendations upon legal rules.

7 ARBITRATION. Arbitration differs from conciliation in two important respects. The arbitration tribunal is a court which bases its conclusions on rules of international law, and these conclusions are binding upon the parties. Their consent to the arbitration is required - either in general terms, in advance of the emergence of any concrete dispute, or ad hoc after its emergence. It is possible for the parties to permit the tribunal to decide ex aequo et bono, $i$. e. as it sees reasonable and just, but if such permission - which is unusual - is not given, the tribunal must base its judgement exclusively on legal rules. The procedure of bringing about solutions to disputes by arbitration has been described in Articles XXVII-XXXI of the Protocol. Article XXVII provides for the establishment of the Arbitral Tribunal, while Article XXVIII sets forth that, recourse to arbitration shall be regarded as Arbitral Tribunal, while Article XXVIII sets forth that, recourse to arbitration shall be regarded as
submission on good faith to the award of the Arbitral Tribunal". It constitutes a legally binding obligation to accept the outcome of the arbitration proceedings. This idea is pointedly repeated in Article XXIX, which concerns a compromise to be concluded by the parties, and specifies:

1 the undertakings of the parties to go to arbitration, and to accept as legally binding the decision of the Tribunal; 2, the subject matter of the controversy, and 3, the Seat of the Tribunal.

The compromise may also specify the kind of law to be applied by the Tribunal; the power, it the parties so agree, to adjuducate ex aequo et bono; the time limit within which the award shall be rendered, and the appointment of agents and counsel to take part in the proceedings before the Tribunal. In the absence of any provision in the compromise regarding the applicable law, the Arbitral Tribunal shall decide the dispute according "to treaties concluded between the parties, International Law, the Charter of the Organisation of African Unity, the Charter of the United Nations and, if the parties agree, ex aequo et bono" (Article III). Emphasis on the confidential nature of arbitration procedure is laid by Article XXXI (1), providing for the hearings to be held in camera unless the arbitrators is laid by Article XXXI (1), providing for the hearings to be held in camera unless the arbitrators
decide otherwise. The Protocol is silent on a number of important questions: Whether the award is to be rendered by a majority vote of the arbiters; the interpretation of an award; the mode of revision of award and whether the award settles the dispute definitively and without appeal. 
Article XII of the Protocol makes it clear that the Commission can deal with disputes between States only. Both parties have to agree to submit their dispute to the Commission and to one of the three methods of settlement. In the absence of such consent by either party the matter is considered by the Council of Ministers. All what could happen, of course, is that a Council would pass a resolution which is only a recommendation not legally binding any of the parties concerned.

It is very significant that the Protocol omits any reference to the judicial means of settlement or to an option for refering disputes to the International Court of Justice. Similarly, neither the Protocol nor the OAU Charter is explicit in defining the relationship between the machinery of the OAU and that of the United Nations for the settlement of disputes arising within the OAU.

The judicial means for the peaceful settlement of disputes generally offers several advantages. For a small State, a judicial settlement eliminates the danger that always exists in settlement by direct negotiation, namely that the relative strength of the other party will influence the outcome of the settlement. Nowhere is the juridical principle of equality of States better respected than in an international tribunal. Furthermore that the judicial settlement takes place by the application of juridical principles. An unsuccessful party often accepts a judicial settlement more easily, without feeling a loss of prestige.

The question of recourse to the International Court of Justice came out already in course of the drafting of the Charter itself, notably in connection with Article 27 concerning the interpretation of the Charter. T. O. Elias commented on the matter as follows:

"After considerable discussion and thought it was considered that disputes as to the interpretation of any of the provision of the Charter would be at best disposed of within the framework of the Organisation itself, rather than by an authority external to it. What in the view of the founding fathers made the International Court of Justice inappropriate in this context was the fact that the majority of the Member States of the OAU, as of United Nations, had yet to accept the compulsory jurisdiction of the World Court ${ }^{8}$."

The Committee which drafted the Protocol adopted a similar attitude. There are a number of reasons why African States are reluctant to refer their disputes to the International Court of Justice. For instance:

1. Few African States, are willing to submit disputes on matters which they consider vital to them for judicial settlement, unless they are absolutely sure of their legal position. The hold the view that, since their vital interests are at stake, the problem cannot be reduced to a simple matter of legal interpretation.

2. The rules of customary international law are often so uncertain that many States may be inclined in their disputes to rely rather upon their bargaining position than upon what they believe is - but cannot be quite sure is - their right.

8 T. O. Elias quoted by Justice Odesanya in the above-mentioned Report (Doc. CM/334/Add. 1.). 
3. Most African States tend to view. present rules of international law primarily as a product of the practice of Western States, and not necessarily reflecting the common interest of all States. They are unwilling to have their disputes settled by these standards, but are prepared to have them settled by standards to which they have themselves agreed. In. this connection they regard the International Court of Justice as an institution predominantly filled with "European judges", and therefore not sufficiently representative of the new international community. The composition of the Court makes them uncertain whether they can get a fair deal there ${ }^{9}$.

Those who did not share this sceptical view of the Court, but on the contrary had often expressed their faith in its impartiality, were shocked by its ruling in the South West Africa Case in July $1966^{10}$.

There is no point in going into any deeper analysis of the various provisions of the Protocol from the simple reason that it had never been applied in the past and hardly ever will be in the future. Despite various attempts to reactivate the Commission ${ }^{11}$ it remained idle. Finally, by the decision of the OAU Assembly in 1970 it became an ad hoc body and the members of itsBur eau (President and two vicepresidents) are serving on parttime basis only.

What is then the explanation for the total neglect of the Commission to which the founding fathers of the OAU attached such a cardinal importance? The answer is in the nature of the Organisation of African Unity itself. The predominantly political character of the Organisation has been reflected equally strongly in the nature of the disputes and crisis between the Member States which were without exception regarded by the parties concerned as "highly political". The President of the Commission, Justice M. A. Odesanya commented as follows:

"The political element in most inter-state disputes even where such political element is noth the predominant one makes States to assume that their vital interests are at stake in every dispute ${ }^{\mathbf{1 2}}$."

The newly independent African States are understandably very sensitive about their sovereign rights. They are proud of their independence, and they resent any outside interference. Hence their refusal to enter into any sort of obligations

9 Hans Blix, a Rapporteur of the Special Committee on Principles of International Law Concerning Friendly Relations and Co-operation among States in 1964, expresses doubts whether one can refer to present international law as a "Western international law", and strongly disagrees with the view that the International Court of Justice should be branded as an exponent of Western international law. He maintains that ${ }^{\alpha}$ in a number of cases, it would appear that the Court has assumed what might perhaps be termed as a "progressive" view of international law, for example in the Norwegian Fisheries Case, the Nottebohm Case, and the Reparations for Injuries Case.

10 In its judgement by eight votes to seven with the President casting decisive vote, the Court rejected the claims of Ethiopia and Liberia against South Africa by ruling that they failed to establish any legal right or interests in the matter before the Court.

11 For example the above-mentioned Report quotes the following statement by the Prime Minister of Sudan to the Third Session of the OAU Assembly in Addis Ababa in 1966. According to the Summary Records the Prime Minister Sayyid Sadik al Mahdi said "That the OAU should be most effective in the area of mediation, conciliation and arbitration. It was therefore necessary to strengthen the Commission and not. allow tendencies to weaken it. The Commission was not as active as it should be mission and not. allow tendencies to weaken it. The Commission was not as active as it should be
There were very many disputes, far too many to cope with. The Commission was vital to the OAU and he therefore supported the proposal to take note of the (President's) report. He called upon the Secretariat to activate the Commission and upon Member States to refer to it in time of need. When bilateral negotiations took place the Commission should be informed. The Commission should set up machinery to strengthen its liaison. Whether the continued permanent employment of staff was needed or not, it was necessary to strengthen the Commission." Doc. CM/334/Add. 1. p. 8.

12 Justice M. A. Odesanya in his inspiring paper "Reflections on the Pacific Settlement of Inter-State Disputes in Africa" given at the Third Annual Conference of the Nigerian Society of International Law held in Lagos in March 1971. The papers were edited by Dr. T. O. Elias and published in 1972 by Ethiope Publishing Corporation in Benin City. 
which would be enforceable by a supra-national authority. "My OAU experience", said Justice M. A. Odesanya, "is that they will always show great reluctance in limiting their own political and diplomatic freedom beyond what they regard as absolutely necessary to secure their immediate objectives ${ }^{13}$ ". It is rather surprising that although the Protocol was drafted after the OAU experienced its first three disputes its draftsmen failed to take any notice of both the principles and the procedure employed in course of their solution. Divorced from the African reality, the Protocol was drafted along the lines of the machinery for the peaceful settlement of disputes of the United Nations which never really worked.

The impotence of the United Nations to effectively employ its peace-keeping machinery provided for in Chapter VI of the Charter was of course very well known to the draftsmen of the Protocol. They hoped to avoid failure by deleting the options of judicial settlement and the recourse to the United Nations ${ }^{14}$.

The ommission of the "compulsory element" in the mechanism of peaceful settlement of disputes which in case of the United Nations is at least in theory, ultimately enforceable by the Security Council, was not enough. It certainly did not disperse the misgivings on part of the OAU Members about an obligation to submit their disputes to the jurisdiction of the Commission of Mediation, Conciliation and Arbitration. It should be pointed out that the establishment and development of the OAU machinery for peaceful settlement of disputes has been largely due to the circumstances under which the need for such a machinery arose.

In 1963, at the Addis Ababa Conference the OAU was certainly not contemplated as a peace maker in Africa equipped with "law, order and peace enforcing machinery". In the atmosphere of newly found unity, solidarity and brotherhood described as the "spirit of Addis Ababa", the possibility of serious disputes among the members was regarded as very unlikely. The setting up the machinery for the peaceful settlement of disputes, provided for by Article XIX of the Charter, was regarded as a formality, certainly not a necessity. Thus when the first disputes arose between the OAU Members, the Organisation was totally unprepared to deal with them. Furthermore early OAU crisis, notably the outbreak of armed hostilities between Algeria and Morocco in October 196315, the Somalia-Ethiopia

13 Ibid.
14 Cfr. Article 20 of the Charter of the Organisation of American States. All international disputes that
may arise between American States shall be submitted to the peaceful procedures set forth in this Charter
before being referred to the Security Council of the United Nations". American Journal of Inter-
national Law, Vol. 58 (1964) pp. 134-138. How bothered were the members of the drafting Committee
about the issue of compulsory jurisdiction reveals the following remark by Dr. T. O. Elias: "In favour of
the compulsory jurisdiction references were made to Articles 3 (4) (which provides that member States,
in pursuit of the purposes of the Organisation, solemnly affirm and declare their adherence to the
principle of the peaceful settlement of disputes by negotiation, mediation, conciliation or arbitration)
and 19 (which provides, inter alia, that member States pledge themselves to settle all disputes among
themselves by peaceful means and, to that end, decide to establish a Commission of Mediation, Concili-
ation and Arbitration). It was felt, however, that these provisions do not ipso facto justify the impo-
sition of a compulsory jurisdiction upon the member States of the Organisation in mediation, conciliation
and arbitration proceedings. It was finally agreed that, if a party to a dispute that has been referred to
the Commission refuses to submit to its jurisdiction, the issue would become political and shouid be
referred back to the Council of Ministers for consideration." T. O. Elias, opus-cit. p. 343 .
15 The armed clash between Morocco and Algeria over was a territorial rather than a border dispute. Mo-
rocco claimed a large area of Algerian-held Sahara, greter in size than the present territory of the
Moroccan kingdom. The presence of important miner resources, particularly oil, in the dispute
territory was undoubtedly a contributing factor in the conflict. The fighting broke out in the second
week of October 1963 , and soon acquired the proportions of a war. This armed conflict was a violation
of the Charter of the OAU, as well as a denial of the spirit which had brought the African States
together at Addis Ababa barely five months before the conflict. With heavy fighting still in progress, 
and Somalia-Kenya disputes ${ }^{16}$ and the crisis in the Congo (Zaire ${ }^{16 a}$ ) gave rise to a special procedure for dealing with such situations. The African leaders realized that these crisis were also crucial tests of the viability of the Organisation and that the outcome of the peace initiative will have a direct bearing upon the fate of the OAU. The OAU approach, was threefold:

1. It depended on the consensus of opinion of both the parties to the disputes and of the African community at large, a method successfully tried out in the Assembly.

2. It was supported by e. g. the recognized "leaders of opinion" in Africa, Emperor Haile Selassie, President William Tubman, President Mobutu Sese Seko and General Gowon.

3. It was based on the strength of the moral obligation of the conflicting parties to abide by the compromise to which they arrive through the mediation and conciliatory efforts of third parties "in the interest of African unity".

The OAU thus evolved its own means for the peaceful settlement of disputes the essence of which has been diplomacy with emphasis on negotiation rather than on the rule of law. In course of ten years, the peaceful mechanism of the OAU has been perfected to the point that it became one of its main assets and an important source of its strength. Its main feature are:

1. African framework which excludes external interference,

2. Employment of the "top level" authority of an individual Head of State or a group of Heads of State formed in a ad hoc mediation or conciliation body,

3. Guiding principles to be applied in various types of conflict.

\section{The African framework}

The desire to solve problems within the African framework has been related partly to the mistrust of external influences common among African statesmen. But is also stems from deeper reservations about the principles of

and the Members of the Council of Ministers of the OAU communicating with the Provisional Secretariat about the proposals for an emergency meeting, Emperor Haile Selassie and President Modibo Keita assumed the role of personal peace-makers and at Bamako made the Heads of State of Algeria and Morocco consent to a common agreement, the stoppage of hostilities and the finding of a solution to the border problem through negotiations in an African framework. The agreement requested an immediate meeting of the Council of Ministers of the OAU, which met on November 15 at Addis Ababa. The resolution adopted by the Council provided for an ad hoc Commission composed of Ethiopia, Ivory Coast, Mali, Nigeria, Senegal, the Sudan and Tanzania, which was to continue the negotiations with the two governments concerned. The only guidance offered by the Council was that the Commission should a as soon as possible establish its own rules of procedure and its working methods, in accordance with the principles and the provisions of the Charter of the OAU and the Rules of Procedure of the Council of Ministers". For the detailed study of the Algerian-Morocco armed dispute see Patricia Wild, "The Organization of African Unity and the Algerian-Moroccan Bordes Conflict", International Organisation, Vol. XX (1966), No. 1, pp. 18-36.

16 There are two parts to the territorial dispute of Ethiopia and the Somali Republic. One part concerns Ethiopia's Northern border with Somalia, and the other her Eastern border. While Ethiopia maintains that her Northern border has been internationally recognised since the Anglo-Ethiopian Treaty of 1897, and admits that only her Eastern border with Somalia is open to settlement, Somalia denies the validity of both Ethiopia's Northern and Eastern borders with the Republic and considers that, on ethnic, cultural and historical grounds, the border territories are entitled to form a Nation-State, that Somali areas under Ethiopian rule have the right to exercise the principle of self-determination and Somali areas under Ethiopian rule have the right
that Ethiopia has the legal duty to grant this right.

16a The breakdown of the representative government in the Congo headed by Cyrille Adoula as Prime Minister and A. Gizenga as his Deputy in 1963 when Gizenga was arrested and Parliament closed down resulted in a civil war. The foreign intervention, the employment of the mercenaries by Moise Tshombe and the repercussions of the Congo crisis on the African continent were discussed inter alia at the emergency session of the OAU Council of Ministers in September 1964. 
international law of the western world. The creation of the OAU rose the hopes of African leaders that they would be able to set their own norms for the conduct of interstate relations, norms which would derive their validity not from the custom and laws of the colonial powers but from the application of the purposes and principles of the OAU. In this respect the OAU assumed the norm creating role by formulating general principles to be observed by the conflicting parties. It totally refrained from pronouncing judgements on specific issues or disputes because this could have created the impression that the OAU was acting as a supra-national authority, a stand the OAU has always declined to adopt.

The principle of settling all inter-African disputes strictly within the African framework was first officially pronounced by Emperor Haile Selassie of Ethiopia ${ }^{17}$. It has since found expression in many OAU resolutions. Thus the resolution on the Algeria-Morocco disput speaks of an "imperative heed of settling all differences between African States by. peaceful means and strictly within an African framework ${ }^{18}$ ". The Resolution on the Congo states that "the Congo problem would find its best solution within the framework of the OAU19" and the Resolution on Nigeria appeals to all Governments and International Organisations ... "to desist from any gesture or attitude likely to jeopardize the efforts of the OAU in finding an African solution to the Nigerian crisis ${ }^{20}$ ".

The OAU's claim of competence to deal also with conflicts involving "actions with respect to threats to the peace, breaches of the peace and acts of aggression" which, strictly speaking, fall within the exclusive competence of the Security Council in accordance with Chapter VII of the UN Charter, has been recognized by the Security Council21. The Security Council, in its Resolution adopted on 30 December 1964 on the situation in the Congo stated that it was "convinced that the Organization of African Unity should be able, in the context of Article 52 of the Charter, to help find a peaceful solution to all the problems and disputes and disputes affecting peace and security in the continent of Africa".

Whether the Security Council's acknowledgement of the primary responsibility of the OAU for African problems was based on pragmatism rather than on competence is irrelevant. This has become apparent in course of the consideration of the Congo crisis by the Security Council in 1964. Firstly, even the Congo which was not satisfied with the role being played by the OAU and its ad hoc Committee it did not challenge the competence of the OAU to deal with the conflict. Secondly, the debate at the Security Council focused on external intervention into the conflict rather than on the frictions between the Congo and other African States. Far from replacing the OAU in the quest for a solution to the crisis the Security Council adopted a resolution that encouraged continuation of the OAU peace-making efforts ${ }^{22}$.

\footnotetext{
17 "Any misunderstandings which arise among brotherly members of this organisation must be essentially considered a family affair" in which no foreign hand can be allowed to play any role whatsoever." "African Research Bulletin", Prototype issue, December, 1963, p. 1.

$18 \mathrm{ECM} / \mathrm{Res} .1$ (1).

$19 \mathrm{ECM} /$ Res. 7 (IV)

$20 \mathrm{AHG} /$ Res. 58 (VI).

21 See B. Andemicael, Peaceful settlement among African States: Roles of the United Nations and the Organisation of African Unity, New York: UNITAR, 1972, p. 46.

22 Ibid p. 47.
} 
The competence of OAU to settle all disputes in Africa is not contradicted by the fact that in certain special cases the OAU itself calls on the United Nations to intervene. These are:

1. Colonialism,

2. Rhodesian crisis,

3. Apartheid policy of South Africa,

4. Illegal occupation of Namibia by South Africa.

These problems are regarded by the OAU as not only having profound international implications but above all that they are United Nations responsibilities under the UN Charter. In the case of Rhodesia also a matter of direct responsibility of a non-African power.

It has been the influence of Africa's eminent statesmen enjoying the confidence of parties engaged in dispute that proved to be able to prevent African interstate disputes from becoming a conflict which would sooner or later involve others and which would jeopardize the existence of the OAU. The African tradition of respecting the wisdom and prestige of the elderly and the men of distinction and integrity found its expression in the freequence with which an African ruler such as Emperor Haile Selassie of Ethiopie had been asked to act as conciliator and as someone who was trusted by both parties to be capable of successful mediation. The experience has shown that African States certainly appear to rely more on an individual statesman or on a collective advice by a group of statesmen than on an international body of professional conciliators, mediators and arbitrators.

\section{Employment of „supreme authority“}

Emperor Haile Selassie of Ethiopia and President Modibo Keita of Mali who assumed the role of personal peace-makers in the Algeria-Morocco dispute in October 1963. The success of the OAU intervention in the dispute between Somalia and Ethiopia and Somalia and Kenya achieved by the collective authority of Africa's Foreign Ministers meeting in an extra-ordinary session convened to Dar-es-Salaam in February 1964. When the dispute flared up again at the 1973 OAU Summit in Addis Ababa the authority of five Heads of State composing the OAU ad hoc mediation committee (Nigeria, Senegal, Liberia, Guinea and Mali) persuaded President Barre of Somalia to co-operate with the Committee in search for a compromise. It was the ad hoc committee consisting of Emperor Haile Selassie of Ethiopia, Presidents William Tubman of Liberia, Modibo Keita of Mali, Julius Nyerere of Tanzania and Gamel Abdul Nasser of Egypt which in 1966 resolved a dispute between Ghana and Guinea following the detention of the Guinea delegation led by Foreign Minister Dr. L. Beavogui travelling to the seventh session of the OAU Council of Ministers by Ghana Government when the plane made an unscheduled landing in Accra. Four Presidents of Central African States (Presidents Tombalbaye of Chad, Bokassa of the Central African Republic, Bango of Gabon and Ahidjo of Cameroon) initiated reconciliation between President Mobutu Sese Seko of Zaire and President Ngouabi of the Congo which led to the signing of the "Manifesto of Reconciliation" on June 16, 1970. Diplomatic relations between the two countries were broken off following the 
"Mulele affair"23". Tension was further increased in 1969 when President Ngouabi accused Zaire of involvement in an attempted coup d'etat in the Congo.

In 1970 Emperor Haile Selassie of Ethiopia was instrumental in bringing about reconciliation between Nigeria on one hand and Ivory Coast, Tanzania and Zambia on the other three of the four countries which recognized Biafra. Gabon was the only one of the four African States which recognized Biafra and refused to normalise relations with Nigeria after the war ended in January 1970. Libreville was used as a staging post for arms supplies to Biafra and a number of Nigerian war orphans were shipped to Gabon and then returned to Nigeria by relief organisations. Eventually, in 1971, Gabon was reconciled with Nigeria through the good offices of Presidents Eyadema of Togo and Ahidjo of Cameroon. President Diori of Niger acted as mediator between Chad and Libya which decided to re-establish diplomatic relations which were broken in August 1971, after Chad accused Libya of interfering in its internal affairs. The communique of April 12, 1972 noted that the two delegations had "examined objectively the causes of misunderstanding, which ended with the breaking of diplomatic relations between the two countries following the events of August, 1971 in which Libya was not involved".

The ad hoc Special Mediation Commission of the OAU presided by Emperor Haile Selassie achieved in 1972 reconciliation between Senegal and Guinea. The authority of the Heads of State was also sought by the OAU Liberation Committee trying in vain to reconcile the rival liberation movements in Angola. President Mobutu of Zaire and President Ngouabi of the Congo held series of meetings with the representations of the two Angolan liberation movements the Popular Movement for the Liberation of Angola (MPLAA) and the Angolan National Liberation Front (FNLA) which eventually led to the reconciliation announced at the 1972 OAU Summit in Rabat. Another example of the employment of "top level authorities" was the ad hoc committee on the Middle East established by the OAU Assembly in 1971 and charged with the task of "seeking the best ways and means of reaching a peaceful and equitable solution to the grave Middle East crisis" composed of 10 Heads of State (Ethiopia, Cameroon, Congo, Ivory Coast, Kenya, Liberia, Mauretania, Nigeria, Senegal and Tanzania).

\section{Guiding principles to be applied in various types of conflict, namely}

a) Boundary and territorial disputes,

b) Charges of subversions,

c) Refugee problems

23 Former associate of Patrice Lumumba and leader of the rebel forces during the Congo Civil War in 1964, granted asylum in the Congo, returned in October 1968 to Kinshasa accompanied by the Congolese Foreign Minister Justin Bomboko with apparent guarantees for his freedom under an amnesty. But immediately upon his return from a trip to North Africa, President Mobutu ordered his arrest and trial as a "war criminal". Mulele was executed by a firing squad in Kinshasa on October 9, 1968. The Government of the Congo enraged by it called a "breach of faith" severed diplomatic relations with Zaire and closed the border between the two countries. 


\section{a) Boundary and territorial disputes}

Among the most explosive of conflicting interests are boundary and territorial disputes ${ }^{24}$. Common tradition and accord have resulted in boundaries not being firmly fixed. In Africa there are few natural frontiers geographically separating one nation from another, and coherent tribal groupings are divided between distinct national Governments. Thus for example the Ewe tribes are divided between Dahomey, Togo and Ghana. Tribal conflict was the cause of the hostilities in Nigeria and the Congo, and between Rwanda and Burundi. Most of these conflicts can be classified as

1. concerning extension of national territory; and

2. concerning the regrouping of tribal, religious or cultural entities, irrespective of the present boundaries.

They are the legacy of colonial frontiers, drawn by the rival colonial powers. Some of them were fixed by administering powers with astoundingly ignorance of political, social, economic and ethnic interests in the areas where the boundary lines now exist. As a result, independent Africa inherited disputes over boundaries or parts of territories between Somalia and Ethiopia, Somalia and Kenya, Algeria and Morocco, disputes involving Moroccan claim over Mauretania and Tunisian claim over parts of Algerian Sahara, dispute between Niger and Dahomey over the island of Lette, and border disputes between Malwi and Zambia, Malawi and Tanzania and between Ghana and the Ivory Coast ${ }^{25}$. The ideas and values prevalent among nationalist leaders at the time of their struggle for independence were very strongly critical of the international borders they were about to inherit on attainment of independence. Their anti-colonialist attitute led them naturally to resent boundaries arbitrarily imposed by the colonial powers. For all those who wished to abolish the entire colonial legacy, a logical corollary would have been to reject also the colonial boundaries. Surprising as it may seem, however, most of the independent African States chose to opt for the preservation of their existing borders. This can perhaps be explained as follows:

First, the majority of African States have not yet achieved internal stability and cohesion; these would be further disturbed by any kind of boundary revision.

Secondly, the maintenance of the status quo began to be associated with the selfpreservation of a State as a political unit. If the right to secede were granted to any group or region, no matter how well justified its claim to self-determination might appear in terms of international law, it was felt that this would stimulate secessionist demands among additional regions or tribal groups, with resulting disintegration of the parent State. Hence the reluctance of the majority of the OAU members to recognise Biafra.

Thirdly, the "tribal balance", on which the political structure of a State often depends, would be upset by any changes of the frontiers dividing tribes between neighbouring States. The annexation of a population could increase the size of a tribe inside the country, which could quickly lead to an internal

24 For a detailed examination of the issue in its legal, political and economic aspects, see African Boundary Problems, edited by Carl Gösta Widstrand (Uppsala, 1968).

25 For a detailed study of the current African boundary conflicts see also Hanspeter F. Strauch, „L'OAU et les conflits frontaliers", Revue française d'études politiques africaines, No. 22 (1967), pp. "59-81. For the recent review of boundary disputes see Saadia Touval, “The Boundary Politics of Independent Africa ", Cambridge: Harvard University Press, 1972. 
conflict. Thus, internal political considerations were an important factor behind the Nigerian Government's opposition to proposals for the annexation of the Yoruba-populated area of Dahomey, or the cautions policies of Gabon and Cameroun regarding the future of Spanish-controlled Rio Muni, the absorption of which could have involved the incorporation of additional Fang in their respective territories ${ }^{26}$.

Finally, the need of the majority of African States to define themselves by means of colonial boundaries led them to the realisation that they have a mutual interest in establishing respect for the status quo. Since many are vulnerable to external incitement for secession, it was obvious to most of the OAU Members that a reciprocal respect for boundaries, and abstention from demands for their immediate revision, would be to their general advantage.

Thus the principle of preserving the status quo found its recognition in the resolution on the "Border Disputes among African States", adopted at the Cairo Summit in $1964^{27}$.

„Considering that border problems constitute a grave and permanent factor of dissension,

Conscious of the eristence of extra-African manoeuvres aimed at dividing African States,

Considering further that the borders of African States, on the day of their independence, constitute a tangible reality ... „Solemnly declares that all Members States pledge themselves to respect the borders existing on their achievment of national independence".

Thus the relative security to be found in the preservation of the status quo, and the search for a legitimising principle to consolidate the existence of African States, converged in the legitimation of the status quo ${ }^{28}$.

The Kenyan "Daily Nation" of June 10, 1970 commenting on the signing of a treaty between Kenya and Ethiopia demarcating the border between the two countries ${ }^{29}$ supports the status quo by the following arguments:

"Most African States are now, through the Charter of the OAU, generally agreed as to the vital need to maintain the boundaries as they had been carved out by the Berlin Conference of the imperialist powers. Several factors are behind this. One of them is that once countries begin conceding to demans for whole tracts of land - whatever the cultural, religious or ethnic justifications - there would be no end to the exercise. Claims would heap upon claims and anarchy would be the result. But the most important factor is that even were there a case for regrouping ourselves according to

\footnotetext{
26 Saadia Touval, "The Sources of the Status Quo and Irredentist Policies", African Boundary Problems (Uppsala, 1968), p. 81.

27 AHG/Res. 16 (i).

28 Saadia Touval, op. cit. p. 82.

29 The agreement was signed in Nairobi by President Jomo Kenyatta and Emperor Haile Selassie during the latter's visit to Kenya from June 8-10, 1970. A joint communiqué said that the two leaders were convinced that the signature of the treaty "represented a triumph for the cause of good neighbourliness harmony, and understanding between neighbouring States". They were confident that "secure and recognised borders helped to foster friendship and co-operation between sovereign States with common borders". The agreement the communiqué said, was regarded as "concrete fulfilment of the principles of friendly relations and co-operation enshrined in the OAU Charter". The agreement in principles of friendly relations and co-operation enshrined in the OAU Charter". The agreement in demarcating the border also regularise the position with regard to watering, grazing and access rights, pre-
servation of law and order, joint inspection of the boundary and its maintenance. Heads of State reaffirmed the necessity for furthering economic, technical, and cultural co-operation between the two countries. They noted that this was the essence of the philosophy behind the foundation of the OAU. It was through co-operation amongst African countries that unity and solidarity could be expressed in a concrete and meaningful manner. Africa Research Bulletin, London, Vol. 7, No. 6, p. 1775.
} 
tribal or ethnic affinities, the implementation would logically result in the proliferation of small units and the balkanisation of the continent into entities that could not possibly be viable economically."

\section{b) Charges of subversion}

At different times, prior to the OAU and after its establishment serious political and ideological differences between various states or group of states often led to mutual charges of subversion. The founding fathers of the OAU fully aware of this problem expressed their "unreserved condemnation, in all its forms, of political assassination as well as of subversive activities on the part of a neighbouring state or any other state" as one of the principles of the Charter. This did not put an end to the serious political quarrels which continued to erupt from time to time between the OAU members of ten causing a major crisis within the OAU. One of such problems was the relationship between Ghana under Kwame Nkrumah and the OCAM (Organisation Commune Africaine et Malgache) which was the successor to the defunct Brazzaville Twelve ${ }^{30}$ strongly opposing President Nkrumah's pan-african policy calling for the creation of Continental Government of Africa, for active part of independent African States in the liberation struggle and his socialist policy at home (not to mention his friendship with the Soviet Union, China and socialist states) they set on the course of political isolation of Ghana. Repeatedly accusing Ghana of subversive activities against the OCAM countries, deeply resenting Ghana's criticism of OCAM's support for Moise Tshombe, they decided to thwart the holding of the OAU Summit scheduled for October 1965 in Accra by declaring their intention to boycott the session. They gave as their reason the presence in Ghana of political dissenters from their countries and allegedly assisted by the Ghana Government in their subversive activities against the OCAM countries. With the Rhodesian crisis looming, the majority of the Member States were more than reluctant to follow the OCAM suit and wedge a rift in the ranks of the African States at the time when the handling of the Rhodesian crisis required unity more urgently than any time before. Besides, Kwame Nkrumah's firm stand on the Rhodesian crisis, and his challenge that Great Britain should be held responsible for its solution won him a great respect in the Organisation. As a result it was the group of OCAM dissenters and not Ghana which found itself in isolation from the rest of the OAU Members. The support for Ghana gained grounds at the extraordinary meeting of the OAU Council of Ministers in Lagos in June 1965 convened to resolve the crisis over the venue of the Summit Conference. At the meeting Ghana took the wind of the sails of OCAM States by agreeing to deport all persons regarded by the OCAM States as "undesirable". Ghana further invited the Chairman of the Council of Ministers and the Administrative Secretary General of the OAU to visit Ghana before the Summit Conference to ascertain the measures it were to be taken towards the success of the Conference ${ }^{31}$.

\footnotetext{
30 See "Tension Among Certain West African States (1965-1967) in A. Andemicael, opus. cit., pp. 39-44. For a detailed analysis of Ghana-Ivory Coast relationship, see Jan Woronoff, West African Wager: Houphouet versus Nkrumah; Scarecrow Press 1972. Metuchen (New Jersey).

$31 \mathrm{ECM} / \mathrm{RES}$. 9 (V), June 13, 1965.
} 
Eight days before the OAU Conference President Kwame Nkrumah himself travelled to Bamako to give his personal assurances to Presidents Houphouet Boigny of Ivory Coast, Hamani Diori of Niger and Maurice Yameogo of Upper Volta of their safety in Accra. Although the "undesirable persons" were removed from Accra, a fact which was confirmed by the OAU Administrative Secretary General, the three Heads of State together and five other OCAM members (Cameroon, Chad, Dahomey, Gabon and Madagascar) declined to attend the Assembly meeting in Accra on the excuse that the undesirable persons were not deported from Ghana as asked and promised in Lagos.

The OCAM boycott revealed the seriousness of the problem of subversive activities in Africa and the urgent need to avoid similar crisis. As a result, the OAU Summit in Accra adopted Declaration on the Problem of Subversion. The Declaration pledges all African States:

1) not to tolerate any subversion originating in their countries against any member of the OAU;

2) to refrain from conducting any press or radio campaigns against any African State

3) not to create dissention within or among Member States by fomenting or aggravating racial, religious, linguistic, ethnic or other differences, and

4) to observe strictly the principles of international law with regard to all political refugees who are nationals of any member-State of the OAU.

Two months later, upon the initiative of the African States at the United Nations joined by the Asian and Latin American States, the General Assembly reaffirmed the principles enunciated in the Accra Declaration by adopting a Declaration on the inadmissibility of intervention in domestic affairs of States ${ }^{32}$. The principles enunciated in the declaration were employed in the subsequent disputes involving the mutual charges of subversion. Again they reached their climax in West Africa and again they centered around the person of Dr. Kwame Nkrumah then deposed by a military coup in February 1966. He took a refuge in Guinea where he was declared by President Sekou Toure as Co-President of Guinea. The insecure military-police regime of General Ankrah in Ghana felt constantly threatened by Kwame Nkrumah and by the country of his residence, Guinea ${ }^{33}$.

Tension arose also between Guinea and Ivory Coast because of the incident involving the seizure of a fishing trawler by Guinea and the detention of the Guinean officials by Ivory Coast mentioned already above.

Last dispute concerning Dr. Kwame Nkrumah erupted between Ghana and Guinea after his death in 1972. Even in death, Dr. Nkrumah did not escape contraversy. This time it was about the return of his body. It was brought from Romania where he died in a hospital to Conacry. The new Ghana regime headed by Colonel Acheampong demanded the handing over of Dr. Nkrumah's remains for burial at his birthplace at Nkroful in Ghana. Guinea agreed, subject to the following conditions:

32 UN General Assembly Resolution 2131 (xx) of 21 December 1965.

33 For example on April 25, 1966 Ghana notified the President of the Security Council of the intentions of Guinea to inyade Ghana. It referred to an alleged statement by President Sekou Touré of March 10, 1966 that 20,000 Guinean ex-servicemen and 50,000 soldiers would be marching to assist the people of Ghana to overthrow the military régime. The Guinean representative to the United Nations flatlydenied the charges and no action was taken by the Security Council. Official Records of the Security council, Doc. S/8120 add. 1, 2. August 14, 1967, pp. 176-177. 
(1) Proclaim President Kwame Nkrumah as legitimate President of the Republic of Ghana who died outside the country and rehabilitate the political and historic work of the great departed and his struggle for Ghana's liberation and the emancipation and unity of the African peoples. (2) Release all his comrades-in-arms being detained in Ghana. (3) Lift the ban forbidding his comrades-in-arms from returning to Ghana. (4) Receive his body with all the honours due to a Head of State and accord him a funeral worthy of his gigantic work in the service of all just causes.

Ghana refused to comply, and the dispute was resolved though the OAU diplomatic efforts.

Of particular significance was the solution of the dispute between Guinea and Senegal announced at the 1972 Summit in Rabat following the meeting of the Special OAU ad hoc Mediation Commission headed by Emperor Haile Selassie and composed of seven heads of State (Presidents Tolberts of Liberia, Ould Daddah of Mauretania, Ahidjo of Cameroon, Traore of Mali, Hauari Boumedienne of Algeria and General Yakubu Gowon of Nigeria) with the Presidents of Guinea and Senegal in Monrovia. The dispute dated from 1971 when Guinea accused Senegal of harbouring refugees implicated in Portuguese sponsored invasion against Guinea in December 1970. The communique signed both by President Sekou Touré and President Leopold Senghor is essentially the application of the principles laid down by the Accra Declaration on subversion linked with the appeal for their unity against the common enemy, Portugal. It contained the following recommendations by the OAU ad hoc Special Mediation Commission:

1. Non-interference in the internal affairs and respect for the sovereignty of States;

2. Undertaking by both parties to prohibit the use of their respective territories as a base for aggression or for hostile acts against each other;

3. Reinforcement of the struggle against the common enemy- - Portuguese colonialism, one of the bridge-heads of imperialism in Africa;

4. Establishment of appropriate and fraternal contacts between the two countries;

5. Cessation of all hostile propaganda through all information media such as Press and radio, publications, etc. .

6. To reaffirm the principle of respect for the rights and privileges of diplomatic representatives of the two countries;

7. Appeals to both Heads of State to use their influence to ensure that an atmosphere of conciliation prevails in the best interest of the brotherly people of the two States and of Africa as a whole ${ }^{34}$.

\section{c) Refugee problems}

There are two categories of refugees in Africa - those from dependent territories and those from independent African States. The first category is closely connected with the liberation efforts directed against the remaining colonial régimes in Africa, notably the Portuguese. It also includes the refugees from South Africa and Rhodesia, as neither country is exactly independent in the eyes of Africans,

34 Africa Contemporary Record 1972-73, edited by C. Legum, London: Rex Collins, 1973, p. C 112. 
but represent a white minority régime oppressing the African majority. Within this category of refugees comes first of all the "freedom fighters" engaged in political activity or even armed struggle against the colonial power. Others are refugees in search of jobs and economic and social betterment, and young people dissatisfied with the colonial conditions and inferior educational opportunities. Fugitives from justice do not qualify as refugees in the political sense of the word.

Much more delicate problems are posed by the refugees from independent African States, who are either victims of political or tribal persecution or are engaged in activities aimed at the overthrow of the existing government in their countries. Some leave their country simply because of dissatisfaction with the policy of the government or just to seek better jobs elsewhere. Independent African States of ten hesitate to give recognition to this class of refugees for fear that, in granting them asylum, they would be suspected of subversive activities against the home State of the refugees.

The magnitude of the problem is outlined in the Background Paper of the United Nations High Commissioner for Refugees of $1971^{35}$ stating that there were about one million refugees in Africa in need of immediate assistance ${ }^{35 a}$.

While all governments are agreed on the need for something to be done for the refugees as a whole, not much has been achieved so far, largely because the question of the classification of refugees (from dependent territories and independent States) has not yet been satisfactorily resolved. On one hand there are humanitarian considerations, but on the other the imperative demand to refrain from "subversive activities on the part of neighbouring States or any other State", as stipulated by Article III (3) of the OAU Charter. The concern of the OAU has been clearly shown in the resolution adopted at the Conference in Accra in 1965. There the Assembly of Heads of State and Government adopted a resolution entitled "the Problem of Refugees in Africa".

On one hand it

"Reaffirms its desire to give all possible assistance to refugees from any Member State on a humanitarian and fraternal basis", on the other it

"Recalls that Member States have pledged themselves to prevent refugees living on their territories from carrying out by any means whatsoever any acts harmful to the interests of other States, Members of the Organisation of African Unity", and "Requests all Member States never to allow the refugee question to become a source of dispute amongst them".

\footnotetext{
35 UNHCR/85/September 1971. For a recent study on the refugee problem see Jan Woronoff: “L'organisation de l'unité africaine et le problème des réfugiés “, in: Revue française d'études politiques africaines, Paris, No. 93, 1973, pp. 86-97.

35a The main refugee groups in Africa are specified by the Paper as follows: 4,000 refugees (mainly from Angola) in Botswana; 40,000 (coming from the Democratic Republic of the Congo and Rwanda) in Burundi; 27,000 (coming from the Sudan as well as from the Democratic Republic of the Congo and Chad) in the Central African Republic; 490,000 (coming from Angola, Rwanda, Sudan and Zambia) in the Democratic Republic of the Congo; 21,000 (coming from Sudan) in from the Democratic Republic of the Congo; 21,000 (coming from Sudan) in Ethiopia; 67,000 (mostly from Portuguese Guinea, with a few hundred coming from other African countries) in Senegal; 61,000 (mostly from Ethiopia, plus 6,000 from the Democratic Republic of the Congo and a few hundred from Chad) in Sudan; 71,500 (mainly from Mozambique and Rwanda, with smaller groups coming from a number of other countries) in Tanzania; 180,000 (from Sudan, Rwanda and the Democratic Republic of the Congo) in Uganda; and 16,000 (mainly from Angola, Mozambique and Namibia) in Zambia. Moreover, there were some 6,000 refugees from various African countries at present living in a number of countries in West Africa (such as Cameroon, Dahomey, Gabon, Ghana, the Republic of Guinea, Ivory Coast, Liberia, Sierra Leone and Togo); as well as with 10,500 refugees to whom asylum was granted in various countries on the African continent, such as Algeria the People's Republic of the Congo, Kenya, Lesotho, Morocco, Swaziland, Tunisia and Egypt.
} 
The problem of refugees has always been of particular concern to the East African States, and in February 1964 they called for a special OAU Commission to consider the matter. When this Commission was set up, it was proposed that certain principles governing the treatment of refugees should be established, and a general African Fund set up to help support refugees throughout the Continent.

These aims were largely met by the "OAU Convention Governing the Specific Aspects of Refugee Problems in Africa ${ }^{36}$ " signed in Addis Ababa on September 6, 1969. The Convention is carefully drafted compromise between the recognized need of "alleviating the misery and suffering of the refugees and providing them with better life and future" and determination not to allow the refugees to become a source of friction among the OAU Member States.

The Convention defines the refugee as "every person who, owing to well-founded fear of being persecuted for reasons of race, religion, nationality, membership of a particular social group or political opinion, is outside the country of his nationality and is unable or, owing to such fear, is unwilling to avail himself of the protection of that country, or who, not having a nationality and being outside the country of his former habitual residence as a result of such events, is unable or, owing to such fear, is unwilling to return to it."

The Convention applies the term "refugee" also to every person who, owing to external aggression, occupation, foreign domination or events seriously disturbing public order in either part or the whole of his country of origin or nationality, is compelled to leave his place of habitual residence in order to seek refuge in another place outside his country of origin or nationality."

Article 4 of the Convention enumerating the circumstances under which the Convention ceases to apply to a person claiming a status of a refuge includes also a case when the person "has been guilty of acts contrary to the purposes and principles of the Organization of African Unity". This would of course exclude any person involved in "subversive activities on the part of neighbouring States or any other States" which would nullify the Convention vis-a-vis persons granted asylum precisely for these reasons - to protect them from extradition to the States claiming their heads. This likely interpretation is further beclouded by provision of Article II concerning asylum which should be regarded as "peaceful and humanitarian act and shall not be regarded as an unfriendly act by any Member State" which does not clearify whether or not the persons fleeing their countries because of charges of subversion are the ones entitled to the "peaceful and humanitarian act" mentioned in Article II. The fundamental rule designed to prevent any disputes or frictions between the country of origin of the refugees and country granting them asylum is laid down in Article III entitled "Prohibition of Subversive Activities". It reads as follows:

1. Every refugee has duties to the country in which he finds himself, which require in particular that he conferms with its laws and regulations as well as with measures taken for the maintenance of public order. He shall also abstain from any subversive activities against any Member State of the OAU.

2. Signatory States undertake to prohibit refugees residing in their respective territories from attacking any State Member of the OAU, by any activity likely

36 For the text of the Convention see Annex. 
to cause tension between Member States, any in particular by use of arms, through the press, or by radio.

It is interesting to note that the Convention refers any dispute concerning its interpretation or application to the Commission of Mediation, Conciliation and Arbitration, presupposing of course "the request of any of the one Parties to the dispute" (Article IX) which leaves the States free to avoid the Commission and seek "political" solution to any such problem in accordance with already established practice of ad hoc bodies.

Another measure adopted by the OAU in order to minimize the frictions arising out of the presence of refugees in various countries was the establishment of the Bureau for the Placement and Education of African Refugees in 1971 (CM/Res. 244, XVIII). It was constituted as a special body under the direct control of the Assistant Secretary General for Political Affairs.

Disputes arising out of non-recognition of certain governments coming to power by coup d'état

While the OAU has been largely successful in peaceful settlement of disputes arising out of a variety of causes, a formula for a policy on recognition of governments coming to power by military coup still remains to be found. Nowhere else in the world has there been such an occurrence - a series of coups d'état within a time span of only a decade.

Since 1960, the year marking the attainment of independence by most African States, there were military coups d'état in 14 countries, (Congo [Zaire], Togo, Dahomey, Algeria, Sudan, Nigeria, Ghana, Uganda, Sierra Leone, Upper Volta, Central African Republic, Mali, Libya and Somalia), not to mention a number of attempted coups or the fact that some of the above-mentioned countries experienced several coups.

\section{The Case of Togo (1963)}

During the early hours of Sunday, January 13, 1963, a military coup d'état was successfully carried out in the Republic of Togo, during the course of which President Olympio was assassinated. Ghana was suspected of having initiated the coup because of her strained relations with Togo over the harbouring of Ghanaian political refugees. Allegations as to Ghana's role in the coup were made publicly by the Nigerian Foreign Minister Jaja Wachuku, who even called a meeting of the Monrovia group to achieve the condemnation of Ghana and the non-recognition of Togo's new Government. At this meeting Jaja Wachuku asked the Conference: "Should automatic recognition be accorded to the provisional Government of Monsieur Grunitzky, without taking into account the suspension of the Constitution, or the dissolution of the Assembly and the abrogation of the electoral laws of the Republic of Togo? . . . Can recognition be decided without taking account of the external influence and of the military constraint which contributed to bring to power and reinforce the new regime?" 
However, depressing as it may be, in international relations law is often the making of the force. The fallacy in the noble principles of recognition of a government preached by Jaja Wachuku at the Lagos Conference was soon exposed in the series of coups détat of which Togo was only the beginning. In 1966 alone six coups d'etat took place two of them, ironically enough, in Nigeria. With the exceptions of the overthrow of Presidents Ben Bella in Algeria (1965), Kwame Nkrumah in Ghana (1966) and Milton Obote in Uganda (1970), the legality of the military governments which came into power was never questioned. Even in the three above mentioned cases "legality" gave way to "reality". When the "status quo", although brought about illegally, acquires the character of permanency its acceptance by other members of the international community, is merely a matter of time. Recognition which is incidentally a political and not a legal act, is being accorded by States for political or economic reasons of their own, or simply because there is nothing they can do about it. The illegal usurpation of power by the white minority settlers in Rhodesia in 1965 is a solitary exception to the rule.

To illustrate how "legality" gave way to "reality" the following is a brief account of how the OAU handled the crises which arose after the overthrow of Dr. Kwame Nkrumah in Ghana (1966) and Milton Obote in Uganda (1971). Both split the ranks of the OAU members into two camps: one refusing to recognize the new regime, the other insisting that any such change is entirely an internal matter.

\section{The Coup in Ghana (1966)}

When after the coup d'état in Ghana on February 24, 1966, a Ghana delegation led by E. T. K. Seddoh representing the new regime headed by the National Liberation Council arrived at Addis Ababa to attend the fifth sesstion of the Council of Ministers, its credentials were questioned by Mali, Guinea, Tanzania and Egypt who objected to the presence of the representatives of the new military regime. After a lengthy debate, the meeting decided to accept the Ghana delegation as a full participant, adding a rider that this was not to imply the recognition of the new Ghana government. The following three days of session were full of suspence in expectation of the announced arrival of the Ghana delegation sent by the deposed President Kwame Nkrumah from Peking and led by his Foreign Minister Alex Quaison Sackey. He, however, chose to travel to Accra instead and placed himself at the service of the National Liberation Council. $\mathrm{He}$ was immediately arrested. The case of the delegations opposing the presence of the delegation led by Mr. Seddoh was thus considerably weakened. But the crisis was yet to come. On the third days of the session when the leader of the Ghana delegation rose to speak, he was stopped by the Chairman of the Political Committee Mohamed Khalil of Sudan, who ruled that the Ghana delegation would not be allowed to speak.

Immediately afterwards, the Chairman of the session, Ethiopia's Ketema Yifrou convened a plenary session to announce dramatic developments. The Chairman then called on the delegate of Guinea Diallo Abdulaye, who told the delegates 
that he had been ordered by his Government to withdraw Guinea's delegation from the session, although not from the OAU. The continued presence of the Ghana delegation, he said, was contrary to OAU principles. Outside the Chamber, Abdulaye said, "Some delegates have become the voices of imperialism. Guinea will not stay in a conference where delegates no longer fight against imperialism, but against the peoples of Africa".

When the Guineans left, Mali Foreign Minister, Ousman Ba leapt to his feet. „Mali cannot sit down with this Ghana delegation", he declared. "We also are leaving the conference". Then it was Tanzania's turn. "It is difficult for Tanzania to stay at this meeting in the presence of the present Ghana delegation. We want unity but unity has principles", said Mr. Oscar Kambona.

Egypt then proposed that the session be adjourned to allow time for tempers to cool, but this received little support. It was the next day that the Egypt delegation withdrew. Its Foreign Minister Ibrahim Khalil announced that Egypt had withdrawn for two reasons - Ghana's continued presence and the "unfortunate atmosphere" between delegates. "We believe the conference should be adjourned for a month or six weeks to allow tensions to abate", he said.

When Algeria left the conference, it was for a different reason - its resolution on Rhodesia was rejected by the majority of members of the Political Committee.

Three more delegations were to leave before the conference ended - Somalia (in protest at a "submissive resolution" then being prepared on Rhodesia): the Congo (Brazzaville) (because of the "deteriorating atmosphere" of the talks); and Kenya. Leading Kenya's delegation out of the talks, Minister of State, Mr. Joseph Murumbi, said the delegation had been ordered to withdraw by President Kenyatta. He added: "We are protesting against the recognition of the Ghana delegation. The Kenya Government is against military coups and disregard of constituted authority. Military coups are a menace to the peace and stability of Africa."

The OAU policy on the crisis was later revealed by the Zambian High Commissioner to Tanzania, A. M. Sembule. He said "It was agreed by the heads of the delegations attending the conference that the attendence by the Ghana representatives did not amount to the recognition by the OAU of the new regime, and it was agreed that if another Ghana delegation Dr. Nkrumah arrived the matter would be rediseussed with a view to excluding both delegations ${ }^{37}$ ".

In the absence of any effective challenge to its authority, the military regime of Ghana was gradually recognized by almost all OAU Members. Apart from Guinea, it was only Zambia which witheld its recognition throughout the four years of military rule in Ghana. President Kenneth Kaunda, personal friend and admirer of Dr. Nkrumah, waited until 1970 when Ghana reverted to the civilian regime headed by Dr. Busia.

\section{The Coup in Uganda (1971)}

The policy of excluding both rival delegations was adhered to by the OAU again in 1971 when President Milton Obote of Uganda was deposed by General Idi Amin.

37 Africa Research Bulletin, London, Vol. 3, No. 3, March 1966, p. 484. 
Soon after President Milton Obote was overthrown on January 25, 1971 by a military coup led by General Amin, the regular meeting of the Council of Ministers of the OAU was convened to Addis Ababa on 26 February 1971. The Ministerial Council, unable to resolve the question of Uganda representation, adjourned sine die on 1st March 1971 and referred the matter to the OAU Summit scheduled for June. The decision was without precedent in the history of the OAU. The situation was of course rather complicated by the fact that Kampala was to be the site of the 1971 meeting of both the Council of Ministers and of the Assembly of Heads of State and Government and that all the top OAU officials Current Chairman of the Council of Ministers Omar Arteh of Somalia and the Administrative Secretary General Diallo Telli - made known their strong disapproval of the overthrow of President Milton Obote. The time, however, worked in favour of General Amin and the rule that the recognition of the new government was for each sovereign state to decide and should not be of concern to the organisation eventually prevailed.

The Council resumed its meeting on June 11, 1971 in Addis Ababa and ended with the statement by its Chairman Omar Arteh, the Foreign Minister of Somalia, who said, "Whatever differences we may have, the ultimate goal is one African Unity".

The credentials of Amin's envoys were recognized but the delegation withdrew from the following meeting of the Council and of the Assembly in protest of changing the venue of the OAU Summit from Kampala to Addis Ababa. The absence of the representatives of the new regime reduced the tension from the meeting, gave Amin one more year which he used to consolidate its power which he did.

The crisis over the recognition of General Amin's regime had its follow-up in turning into a conflict between Uganda and Tanzania ${ }^{38}$.

The President of the Commission of Mediation, Conciliation and Arbitration, Justice Odesanya, in his "Reflections on the Pacific Settlement of Inter-State Disputes in Africa" raises a number of relevant questions referring to the problem of disputes arising out of the change of governments through violent means:

38 The strained relations between Tanzania and Uganda dates from 1971 when General Amin overthrew President Obote who found refuge in Tanzania which since has refused to recognize the legality of Amin's rule. In September 1972 supporters of ex-President Obote launched an armed attack from the Tanzanian territory against Uganda. The invasion failed but brought the two countries to the brink of war. At the OAU Anniversary Summit in Addis Ababa in May 1973 the matter was further exarbated by a letter of the deposed President Milton Obote addressed to all African leaders in which he accuses General Amin of the murder of 80.000 Ugandas. The letter describes the horrors of the execution, torture and atrocities which according to Dr. Milton Obote had assumed the proportions of a genocide. The detailed description of the events in Uganda include macabre accounts of orgies in which Amin soldiers allegedly cut parts of the bodies of the victims, roasted the human flesh and fed the starving victims on their own flesh until they died. However, Dr. Obote's appeal to the OAU "that a large scale slaughter of Africans in any part of Africa must concern the OAU" fell on deaf ears. The principle of non-interference into the internal affairs of member states to which the OAU rigidly adheres prevailed and the Ugandans were left to their fate. The high tension between the Ugandan and Tanzania delegations at the OAU Anniversary Summit in Addis Ababa in May 1973 were broken by and Tanzania delegations at the OAU Anniversary Summit in Addis Ababa in May 1973 were broken by
General Amin's suggestion to add the name of Dr. Milton Obote to the list of distinguished Africans to be awarded a special medal marking the OAU's tenth anniversary. General Amin thus made it abundantly clear that while he is prepared to recognize Obote's contributions to the cause of African unity he definitely wrote him off as a potential political rival in Uganda. Tanzania seconded the proposal and the ice was broken. Amin then publicly called Nyerere his brother against whom he bears no grievance and offered him a handshake which President Nyerere accepted. More tangible outcome of the reconciliation between the two leaders was an agreement concluded under the auspiecies of the host to the meeting Emperor Haile Selassie, providing for the following:

1. Uganda accepts responsibility for the deaths of 24 Tanzanians in Uganda and agrees to pay compensation;

2. Both parties undertakes to see to it that its territory is not used for subversion against the other;

3. Tanzania undertakes that President Obote will not interfer in the internal affairs of Uganda; and

4. Uganda will not demand the eviction of Dr. Obote from Tanzania. 
1. When a constitutional government is overthrown by force in Africa, it is the business of any member State of the OAU to question the justification of the coup d'état by reference to domestic conditions within the State or to ask whether the army violated the constitution.

2. Is it necessary to summon an ad hoc meeting of the Heads of State, and Government or the Council of Ministers to find out whether in the overthrow of the government there was foreign government complicity or aid?

3. Has any member State the right to question the representative character of the new government?

4. Should we have clearly defined OAU policies on these matters to prevent disputes in the future.

His colleague, Dr. T. O. Elias, offers legal guidance on what are the "basic requirements for a coup d'état to become a proper and effective legal means of changing a government:

(a) There must have been an abrupt political change, i. e., a doup d'état or a revolution. It does not matter whether the change has been effected directly by a military junta or by a civilian or group of civilians subverting the existing legal order with or without the aid of the military. There can be a coup without the use of armed force.

(b) The change must not have been within the contemplation of an existing Constitution. If it were, then the change would be merely evolutionary, i. e. constitutional; it would not have been revolutionary.

(c) In order for the coup d'état to be complete, the new regime need not have abrogated the entire existing constitution. It is sufficient that what remains of it has been permitted by the revolutionary regime.

(d) The new constitution and Government must be effective. There must not be a concurrent rival regime or authority functioning within or in respect of the same territory ${ }^{39}$. Experience has shown that the decisive criteria for recognition of the new military government by the Organisation of African Unity is to be the new government's foreign rather domestic policy. The new government shall therefore be judged on the strength of its performance in pursuance of the principle aims of the Organisation - liberation of dependent territories and eradication of apartheid. This has been quickly grasped by General Amin who turned from a champion of dialogue with South Africa to one of the staunchest supporters of the OAU Liberation Committee offering Ungada's territory as a base for training the freedom fighters and urging other OAU members to step up their aid to the liberation movements.

\section{The future for the Commission of Mediation, Conciliation and Arbitration?}

For as long as the settlement of inter-State disputes in Africa remains in the hands of politicians, which seems to be still quite a long term prospect, the place of the Commission of Mediation, Conciliation and Arbitration can only be auxiliary. This

39 T. O. Elias, Africa and the Development of International Law, Leiden: A. W. Sijthoff, 1972, pp. 108109. 
is not to belittle its importance. The Bureau of the Commission as well as its members could provide invaluable services by offering legal advice to the various ad hoc political bodies performing the role of mediators or conciliators.

By becoming gradually involved in the existing procedure for peaceful settlement of disputes, the Commission might be then assigned to deal first with the legal aspects of the dispute in question and subsequently to assume its responsibilities assigned it by the OAU Charter and the Protocol.

To convince African States, which are very sensitive to any infringement of sovereignty, which they still see in submitting their internal dispute to a supranational authority even with such minimal "supranational powers" as the Committee of Mediation, Conciliation and Arbitration will be a lengthy if rewarding process. 


\section{By Zdenek Červenka}

In the field of peaceful settlements of disputes, the record of the OAU is certainly more impressive than that of the United Nations Organisation. One of the most interesting aspects of the OAU's handling of disputes and crises has been the fact that these disputes and crises were resolved not by the organ created specially for that purpose, the "Commission of Mediation, Conciliation and Arbitration", but by political negotiations which in most cases were based on the private initiative of African leaders. African leaders enjoying the status of "leaders of opinion" in Africa, men of stature - Emperor Haile Selassie of Ethiopia, the late President William Tubman, and most recently the most successful officers turned politicians - Presidents Mobutu of Zaire and General Gowon of Nigeria.

The OAU thus evolved its own mechanism for the peaceful settlement of disputes, the essence of which has been diplomacy rather than rules of law. Its main features are:

1. Emphasis on the settlement within the African framework, excluding any outside interference.

2. Employment of the "top level" authority of an individual Head of State or a group of Heads of State.

3. The laying down of guiding principles to be applied in various situations leading to a conflict

The resolutions adopted by the OAU on "Border Disputes" among African States, "Declaration on the Problem of Subversion and the Resolution on the Problem of Refugees in Africa" are examples of the rules agreed upon by the OAU MEMBERS. The article also analyses the problem of the "recognition of new regimes" which came to power by coups d'état and which too gave rise to disputes and even conflicts. However, in most cases the "legality" always gave way to "reality".

Finally, the author raises the question regarding the future of the Commission of Mediation, Conciliation and Arbitration, which he sees in a gradual process of getting involved in the political settlement of disputes and providing the political leaders, charged with the task of settling a particular dispute, with qualified legal advice.

\section{Traditional Law Under French Colonial Rule}

\section{By Kwame OPOKU}

Despite all declarations of their intention to respect African institutions, the French subordinated African law to French law. They divided the inhabitants of their colonies in West Africa into two groups: citizens and non-citizens. French citizens were subject to French law and non-citizens were governed by African law. The inhabitants of the old communes of Senegal (Dakar, Gorée, St. Louis and Rufisque) were granted citizenship but allowed to settle their private law matters in accordance with African traditional law. Africans in other parts of the colonies 